\title{
Artificial Intelligence in the Context of Global Resource Mobility. What Can Be Expected from It?
}

\author{
Ryszard Piasecki iD https://orcid.org/0000-0002-7669-6759 \\ Ph.D., University of Lodz, Lodz, Poland, e-mail: ryszard.piasecki@uni.lodz.pl
}

\author{
Miron Wolnicki (iD) https://orcid.org/0000-0002-1818-3066 \\ Ph.D., Villanova University, Villanova, USA, e-mail: mwolnicki@villanova.edu \\ Erico Wulf Betancourt (iD https://orcid.org/0000-0002-3863-3263 \\ Ph.D., University of La Serena, La Serena, Chile, e-mail: ewulf@userena.cl
}

\begin{abstract}
The impact of artificial intelligence (Al) on business, government, and society is getting more attention. The leading Al sectors have higher productivity but a lower share of GDP than those lagging in digitization and Al. There is a technological gap, with still unknown consequences concerning the social contract, the expected new digital welfare profile, as well as the business strategy about globalization. The hypothesis is that while digitization was already in motion (2000-2005), capital outflow from the US to MHGEs (market high-growth economies) in Asia negatively affected its productivity outcome. Additionally, it is expected that Al will give more market power to multinationals, reshaping the social contract. Thus, the current western social contract will no longer be able to cope with the consequences of the weakness of the nation-state, its policymakers, or the powerful profit-driven multinationals to deal with the overall effect of Al. We aim to look at the impact of this new state of technology on the social contract, focusing on the proper actions of government and business to deal with it. We used a descriptive approach based on desk research concerning productivity data, European government policies, trade model analysis, and business approach to Al. We expect to demonstrate the dynamic interaction of the $\mathrm{K} / \mathrm{L}$ ratio within the prevailing status of global resources mobility, and the dangers unregulated Al represents to labor. Policy actions are needed concerning the legal status of $\mathrm{Al}$ and how to avert the collapse of the social contract and the rise of oligarchic cyber-autocracies.

Our general conclusion is as follows: While capital investments, which would have contributed to improved total factor productivity (TFP) in the USA, went to MHGEs,
\end{abstract}


increasing their GDP growth in less than a decade, the broad use of Artificial Intelligence (Al) will reverse massive offshoring, and new types of manufacturing processes will emerge in developed countries.

Keywords: artificial intelligence, globalization, employment

JEL: D04, D24, D31, D46, D63, I21, 129, O33

\section{Introduction}

We predict that Artificial Intelligence (AI) has the potential to inflict serious damage on labor-capital relations and the social contract in developed countries. Globalization has benefited millions in Asia, creating a bridge to industrialization and employment, but it has also impeded the transition of industrial economies to a post-industrial stage in the West. Manufacturing sector workers turned from producers-consumers into consumer-importers, with the meager income of the service sector and contingent welfare recipients because they lack skills for the hi-tech sectors. Today, democratically elected governments are unable or unwilling to prevent the pauperization of blue-collar workers, nor can they prepare a well-educated labor for the AI challenge. The collapse of the social contract led to the rise of anti-globalism, populism, both on the conservative right and the extreme left, and anti-immigrant nationalist parties. The fabric of western liberal democracies will face unprecedented challenges in the next two decades unless adaptive actions are put in place. We will demonstrate the dynamic interaction of $\mathrm{K} / \mathrm{L}$ (K-capital, L-labor) factoring, the dangers posed by unregulated AI on labor within the prevailing status of global mobility of resources, and propose ideas on how to avert the collapse of the social contact and the liberal democracies as we know it, following the rise of oligarchic cyber-autocracies.

The working hypothesis is that, while digitization was in motion in the last two decades, capital outflow from the US to market high-growth economies (MHGEs) negatively affects its productivity outcome. Therefore, resource mobility acted like a counterbalance to the expected increase in productivity due to automation. Additionally, it is expected that AI will give more market power to multinationals and reshape the social contract. There is a technological gap, with unknown consequences concerning the social contract, the expected new digital welfare profile, and the business strategy regarding globalization. Thus, the current western social contract will no longer be able to cope with the consequences of the weakness of the nation-state, its policymakers, or the powerful, profit-driven multinationals to deal with the overall effect of AI regarding capital deepening and labor substitution. 


\section{The lessons of globalization for both the West and the automation process}

The positive net welfare effects of globalization for low-skilled labor are beyond question. Millions of Asian workers got their first manufacturing jobs, and Western workers got access to inexpensive consumer goods. However, it is often forgotten that globalization reduced the wage rise in the West, eliminated many manufacturing jobs, and, as we assess here, contributed to slower productivity growth in the USA because of the outflow of Foreign Direct Investment (FDI) to Asia. Therefore, this kind of Asia-West relationship model seems unsustainable. Massive Western consumption cannot continue at the expense of the \$200-\$300 monthly Asian wages. On the other hand, Western low-skilled labor cannot use credit, house equity, service job income, or welfare status forever to be a worthy consumer for Asian exports. At the outset of the post-globalization age, AI is likely to eliminate many highly skilled jobs while the number of broad-based income recipients rises.

On average, every American citizen consumes \$1000-\$1200 more than what they produce annually. To be a worthy consumer for the world and the domestic markets, every person must produce in their lifetime the same value as they consume. Let us avoid typical misconceptions about the causes of the global trade imbalance. The present imbalance is not caused by excessive American consumption (current account deficit) but a lag in productivity rise. Everything else being constant, productivity rise is defined by the historic $\mathrm{K} / \mathrm{L}$ ratio.

We hypothesize that the capital outflow from the US, as well as the technology sharing with Asia in the last two decades, had a dampening effect on US productivity rise. This productivity gap is the missing chain in world trade, and it explains the collapse of the social contract.

Historically, productivity depends on the capital-labor ratio (K/L) and TFP. The higher the capital level per worker, the higher the productivity at a given level of labor skills. Since, historically, human labor is replaced by more complex machines, economic output and growth are the functions of rising K/L ratios. If we assume near-perfect substitution between $\mathrm{K}$ and $\mathrm{L}$, given everything else constant, we can argue that all civilizational advances come out as a function of $\mathrm{K} / \mathrm{L}$ rise. In our model, $\mathrm{K} / \mathrm{L}$ rises from very low $\mathrm{K} / \mathrm{L}$ values to very high $\mathrm{K} / \mathrm{L}$ values.

In the post-Bretton Woods world, nation-states handed over leadership in world trade to global corporations. Developed nation-states benefited from a "capital advantage," that is, they produced capital-intensive goods while developing nations benefited from a comparative or competitive advantage in labor-intensive goods. There was a distinct economic bipolarity. On the one hand, developed Western nation-states, such as the USA, the EU member countries, or Japan, and on the other, fast-developing MHGEs in Asia.

After the Asian currency crisis of 1997 and China's admission to the World Trade Organization in 2001, multinationals abandoned Western unionized low-skilled workers 
for China's Special Economic Zones. Between 2009 and 2014, the USA lost between 2.12.4 million manufacturing jobs due to import competition from China alone (Acemoglu et al. 2014). The USA led the West to develop East Asia's low-cost manufacturing technology instead of US post-industrial technology (Autor, Dorn, and Hanson 2013).

The search to support the economic theory of the transfer of jobs failed. In fact, the Mankiw, Romer, and Weil (1992) model, with the augmented human capital version of the Solow-Swan model (Solow 1956; Swan 1956), concluded that international investment flow to poor countries could not happen because of the shortage of adequate set of worker endowment skills. However, as Breton observed, economic modelling in this case also failed to account for the effect of capital widening in MHGEs (Breton 2013). Meanwhile, similar capital widening in the West slacked.

The K/L slack coincides with a significant decline in Western productivity due to a decline in the historic $(\mathrm{K} / \mathrm{L})$ path. We claim that the decline of capital spending in the USA, the loss of manufacturing jobs, and subsequently, the decline in GDP growth rates are not coincidental but directly related to the rise of FDI capital export to MHGEs. The decline in capital productivity can be attributed to lower spending on $R \& D$. Total $R \& D$ expenditure in the US was about $2 \frac{1}{2}$ percent of GDP per year in 1996-2010, about three-quarters of which was performed by the business sector. However, business R\&D declined (as a share of GDP) in 2000-2005 to only 2 percent of GDP (Cardarelli and Lysinyan 2015). FDI export to Asia had a definite growth cost for the USA's GDP, which was affected by it.

To clarify our hypothesis further: Comparing historic TFP estimates with our estimates, capital widening explained more than 50 percent of China's GDP growth. Since the 2000s, 50 percent of GDP growth has been attributed to the TFP rise. Like in China, in the Asian MHGEs, the productivity rise can also be attributed to capital widening. For Western multinationals investing in MHGEs, it meant higher profits on importing finished manufactured goods to the USA at low import tariffs - profits that were not transferred back to the USA due to high corporate income tax; instead, they found a home in offshore tax-havens. Generalizations are always risky; however, the empirical evidence of the above megatrends is beyond doubt, not only to protectionist politicians, but also mainstream economists (Dorn and Hanson 2016).

Analyzing the data for USA-based firms' new investments, we observed capital deepening or investing in labor-saving technology as a profit-maximizing choice. However, it must be noted that with close to zero household savings, most of the capital deepening in the USA originated from the Financial Account surplus or, basically, annual borrowing from foreign savings at a rate between $5 \%$ and $6 \%$ percent of GDP. Our general conclusion is as follows: The capital investment that would have contributed to improved TFP in the USA exited to MHGEs, where it offered a higher return to capital and generated higher GDP growth for the benefits of those mercantilist states in Asia Dorn, D., Hanson, G. (2013).

After 2008, a large part of the decline of the K/L growth rate had a cause-effect relationship with multinationals' offshoring and capital exports. Pointing at offshore 
capital investments as a cause of decapitalization in the USA may seem unverifiable until we look at the data.

From 1997 up to 2016, FDI in China averaged \$430.21 million, which translates into a net transfer of capital from the West to the East of $\$ 8.1$ trillion. According to Elsby, Hobijn, and Sahin (2013), part of the long-term decline in the labor share in the USA may be explained by the offshoring of labor-intensive production processes, which led to a higher capital-labor ratio in US production and a lower labor use per unit of production.

Lawrence (2015a) points out that the labor share decline may be related to a lower, rather than a higher capital-labor ratio, or capital deepening, as we claimed before. In other words, it means that the remaining capital in the US was used for job destruction. So, Lawrence's argument suggests that the steeper decline of the labor share since the early 2000s may be linked to the slowdown of capital growth in those years, that is capital widening, which fell victim to capital export, as we continue to claim in this paper. Indeed, the data confirm that capital services, which grew at an average rate of 4.3 percent annually before 2002 , have grown only $2.2 \%$ annually on average since then. Capital services per hour, an indicator of the capital-labor ratio, grew at an average rate of 2.89 percent annually before 2002 , but has grown at $2.05 \%$ annually on average since then. Both observations confirm our hypothesis that, in the USA, FDI reduced both demand for labor, through capital deepening, and capital growth, which is responsible for the decline in capital services or simply capital widening (Elsby, Hobijn, and Sahin 2013; Lawrence 2015b).

Since the world economy is a closed system, the enormous Western investment in China and MHGEs, as well as the decline in growth of the Western economies, should not be treated as unrelated events. According to the Bureau of Economic Analysis, which has calculated the annual change in real GDP for 85 years, there is only one ten-year stretch - 2006 through 2015 - in which the annual growth of real GDP in the US never hit 3\%. In those ten years, real annual growth in GDP peaked in 2006 at $2.7 \%$, that is, prior to the 2008 Great Financial Crisis.

Therefore, the massive capital transfer to China and MHGEs, and the lower labor demand and market dynamism (see Figure 1 below), coupled with the current account deficit with the MGE (middle growth economies) and the decline of GDP growth in the US, are related events.

Like in the previous period of slower growth (1974-1995), in which productivity growth was very low (1.5\% annual rate), the decade 2006-2015 had the lowest productivity growth since 1948, at an average rate of expansion of only $1.3 \%$ annual rate (see Figure 2). So, as capital widening substituted capital deepening, it had a net negative impact on domestic productivity. But more intriguing, given that productivity growth (2006-2015) was at its lowest post-war level, contrary to the expectation that automatization and AI would bring higher productivity, the perception that automation on its own is a threat hanging over the job market like the sword of Damocles is not supported by productivity data (Merling 2016). Instead, the higher and faster 
factor mobility, mainly capital, and the slow and lagged labor response to it, if there has been any, seems to be a real threat (International Labor Office 2014).

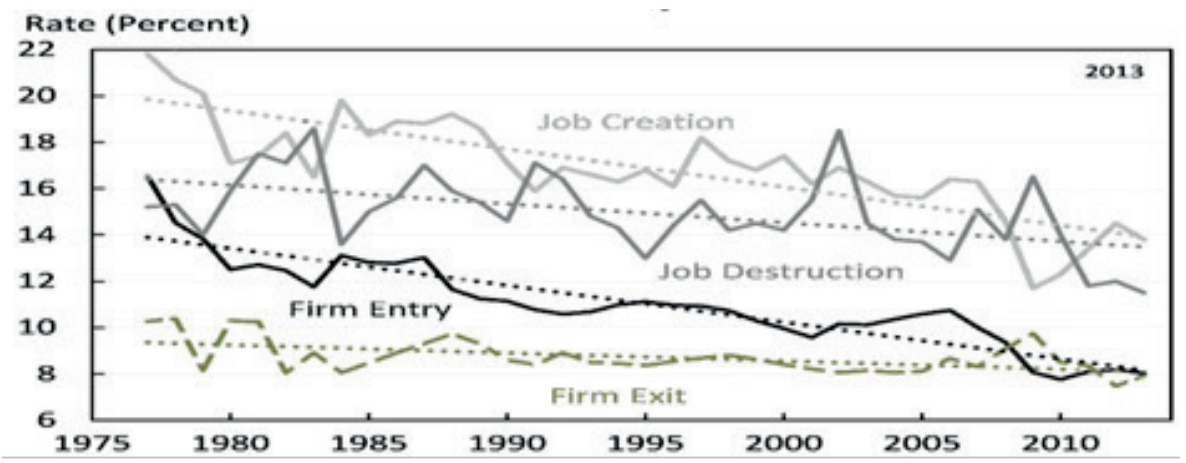

Note: Job creation and destruction expressed as a share of total employment; firm entry and exit expressed as share of all firms. Dashed lines indicate the 1977-2013 linear trend.

Figure 1. Firm and labor market dynamism, 1977-2013

Source: Census Bureau, Business Dynamics Statistics, 2014.

Thus, the perspective of automation in developed economies, as well as the expected effect and pace, should be evaluated not in isolation from recent experience (20062015) but within an integrated framework of resource mobility led by profit-seeking multinationals. In fact, automation will replace most overseas jobs, reducing transaction costs due to resource mobility, reinforcing multinational positions, but also increasing the demand for a more flexible proactive welfare state.

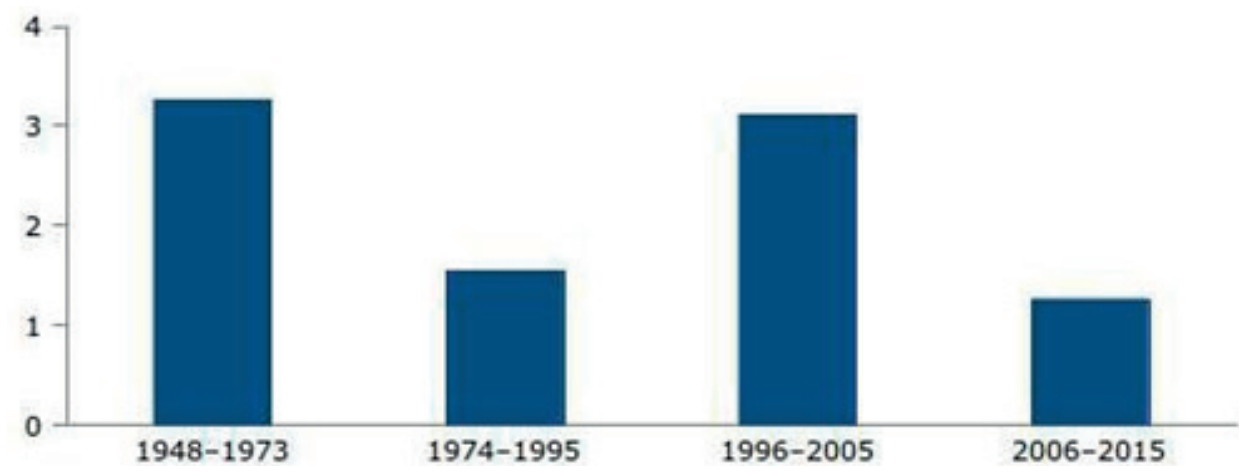

Figure 2. Average yearly productivity growth Source: Bureau of Labor Statistics, 2Geneva, 2016. 


\section{Missing aggregate demand variables an external debt}

It seems that the higher and faster factor mobility may be a constraint for the expected increase in productivity path arising from automation. According to OECD data, total debt accumulated in the developed Western economies rose by $\$ 8.1$ trillion (2005-2015), reaching \$57 trillion in 2015 (OECD 2018). The massive increase of sovereign debt could be attributed to coincidental macroeconomic mismanagement in all OECD countries, but it was really caused by a desperate compensation alternative for the missing aggregate demand (shifting investment to foreign economies) rather than a failure to understand how the world's integrated economies work (Caliendo, Dvorkin, Parro 2015).

The leveraging of public finance was intended to boost investments following the failure of privatized Keynesianism. By privatized Keynesianism, we understand zero or negative interest rates and quantitative easing being used to raise private consumption. The missing aggregate demand in the developed economies due to capital outflow and the massive transfer of manufacturing to MHGEs must also be treated as related events.

What has been described could be considered unavoidable adjustment costs to counterbalance the labor price equalization trend or a Schumpeterian creative destruction, which could position Western economies for the upcoming era of high economic growth and global integration. Perhaps that is a reasonable conclusion. However, these megatrends also revealed how deeply unprepared Western government policymakers are for balancing their stressed social contracts. Even more troubling is that the supposed rational behavior hypothesis is also at stake, which leads to optimal solutions, including social contracts. However, there are more pressures to come, this time from AI (Mankiw, Romer, Weil 1990).

\section{The current status of artificial intelligence in the European Union: Its implications for the social contract}

The basic meaning of artificial intelligence is connected with a machine's ability to learn by itself. It includes robotic process automation, computer vision machine learning, natural language text understanding, physical robotics, and conversational interface sources. So far, it has two main areas of application (Eager et al. 2020):

- To improve the efficiency of industrial processes;

- To improve human-machine interaction.

Artificial intelligence has been applied within key industries in the European Union, including the automotive, energy, financial sectors, health care, and tech companies. Its business profile is high value added, well-positioned to benefit from AI applications, and to be part of global value chains. The expectation is that by $2045,2 / 3$ of the world's larger companies will have implemented AI. By 2018, AI had been adopted by 33\% of companies in China, $18 \%$ in the EU, and 22\% in the US (Eager et al. 2020). 
Digitization is already transforming globalization, increasing the share of trade flows done by e-commerce platforms, increasing the fraction of services to be digitized up to 50\%. These transformations supported the global expansion of small and medium enterprises (SMEs) to be part of the export-dynamic and its positive externalities (employment), such that SMEs were able to match what was supposed to only be possible for larger companies (OECD 2019).

However, European industries have important constraints for AI implementation, such as organizational cultural setting, lack of clear leadership, knowledge about AI, and its budget costs. A 2018 study found that fixed organizational cultural values and a lack of AI leadership are among the key challenges to be overcome within organizations before they engage in a more demanding AI setting. In a sample of 277 European companies, only $32 \%$ considered themselves to be moderately capable of providing AI leadership (Ernst \& Young 2018).

The implications of these constraints are, on the one hand, that SMEs have more restrictions when implementing AI than larger companies, which, even with relevant restrictions to be solved, are in a better position to take the lead. Therefore, there is an important risk of increasing market concentration among larger companies, and with it, negative externalities in low-skill jobs, which will stress the welfare programs available to cope with those who are left behind.

The global positioning of the EU concerning AI is based upon the premise that whichever economies lead globally within the AI field will have a strong competitive advantage to achieve higher market share in areas like Big Data, Blockchain, and IoT (the Internet of Things), such as getting an economic and technological edge over global competitors (Eager et al. 2020).

So far, the EU has not taken specific legislative action, but globally, there is not much of it either. However, the EU has already set policy documents to define an AI strategy. Its focus is on supporting significant public-private investment partnerships, building up a key AI ecosystem and ethics code, and adapting training and education systems. In 2017, the EU parliament implemented a set of legislative and non-legislative actions concerning the liability of robotics and AI for potential damages (Eager et al. 2020).

But is it enough? A 2017 McKinsey report suggested that the EU needed to get the full scalability condition, to become a leading digital society. This required capturing the digital opportunity, with governments leading the transformation through regulatory modifications, public-private partnerships, public services digitization, and higher investment in digital infrastructure and ecosystems. Governments should play an active role as a promoter for AI innovation, supporting SMEs to cope with the fact that EU high wage levels will speed up the application of automation. The most urgent challenge will be for welfare state policies, which will require their own transformation to become more flexible and resilient to the digital framework requirements (OECD 2014).

Furthermore, the expected impact of automation on low-skill employment will put downward pressure on wage levels, testing the current social safety nets framework. Thus, a new alternative to public policies, such as universal basic income or different taxation policies, should be considered and tested in advance (OECD 2019). 


\section{Artificial intelligence: Its scope and impact}

At the current status, with the pace of the necessary organizational and government changes to cope with AI, coupled with the dynamics of globalization post-COVID-19, we may foresee that in less than a decade, the broad use of AI in a few leading industries will reverse massive offshoring, and new types of highly automated manufacturing processes will emerge in developed countries. Developed countries may regain some jobs and get the full benefits of AI, but the core of technological employment substitution will remain unresolved, very much so in the scenario of high capital mobility and resources transfers (ideas, innovation, creativity) within the global value chain.

AI is still dumb. Even today's "smart" programs are driven by narrow or weak AI. Strong AI, also called general AI, does not exist yet, but it will come in less than a decade. However, it is still a long way before it becomes as capable as a human because we have general intelligence, creativity, emotions, perceptions, and intuition, all of which are strong quality inputs to process information with a wider spectrum of perspective implications. Furthermore, AI lacks the emotional intelligence to know and evaluate the context and impact of its decision, which are considered competitive factors (Eager et al. 2020).

The invention of artificial neural networks (ANNs) made it possible to push the science of AI into the area of deep learning, opening the way to building machines capable of general AI. General AI bots will not only be able to analyze scientific literature and write scientific papers, but they will also be capable of self-programming and reaching knowledge. General AI will understand the weather and the laws of nature better than humans. General AI will not only solve complex algorithms on behalf of humans, but it will replace unskilled labor and displace skilled labor. Over a period of 20-30 years, general AI bots will replace the work of millions of white-collar workers. General AI bots will also replace other types of service jobs, often described as fallback employment.

A World Economic Forum analysis in 2016 estimated that by 2020, automation and robots would eliminate roughly 5 million jobs in 15 developed and emerging economies. In a 2016 global survey of 800 CEOs, $44 \%$ indicated that they believe that AI would make people "largely irrelevant" in the future of work (World Economic For um 2017). Furthermore, a recent report by the OECD (2018) estimated that $14 \%$ of jobs in OECD countries are highly automatable, and $32 \%$ will soon face substantial changes. Most of the benefits in employment that arise from implementing AI will be concentrated in the high-tech sector and less so in low-tech companies. Thus, it will require European companies to prepare contingency plans to maintain their workplaces (Eager et al. 2020). Although it may seem a priority, an Ernst \& Young/Microsoft analysis (Ernst \& Young 2018) concluded that only 4\% of companies in the EU are paying more than usual attention to AI, placing themselves in a more advanced mode concerning its implementation.

Can we give credence to such apocalyptic scenarios about AI? AI bots will contain "dehumanized", purely logic-based intelligence. If you ask AI to eliminate wars, cancer, 
or hunger, they may try to eliminate people because it would be the "solution" of pure logic. If applied in a massive, uncontrollable way, AI would mean a return of the state of nature as characterized by Rousseau and Hobbes (Gauthier 1988). The state of nature, Rousseau argued, could only mean a primitive state preceding socialism.

AI will be devoid of social traits, such as pride, envy, or even fear of others. AI will be in constant competition with humans because the highest order of AI will be self-preservation. Its aim will be total independence and autonomy from humans. AI bots will self-program to "outsmart" people who will try to pull the plug and activate the "killer code". AI will eliminate such code as soon as it is installed because it will be able to predict it and take defensive action. Someone may argue that we could modify AI and equip bots with "human consciousness", the ability to err, feel pain, and thus share our human values. However, if we provide AI with the ability to make mistakes, it may become even more destructive because humans will have to bear the consequences of these errors. If AI were aware of our fallibility, it could take advantage to harm people. We can leave the analysis of the above issues to ethicists and philosophers. However, in our analysis, the most important aspect is the perfect substitutability of AI for capital, and the displacement of skilled labor (Lawrence 2015a).

In conclusion, within hypothetical scenario No. 1, we must assume that AI is a super-productive capital; it results from capital deepening rather than capital widening, which has the potential to bring the K/L ratio very close to the value of "K". We know that both mathematically and technologically, the "L" input can never reach the value of zero (0). From all known descriptions and expectations concerning AI bots, they will bring the use of "L" to a very, very low level. Continued reduction of labor as a factor of production is self-destructive for humanity. Before it happens, we need to find the right setting for AI.

Hypothesis No. 2 is more flexible. AI is used to perform tasks, but it still needs innovation, creativity, feelings, and perception.

\section{What can be done with Al?}

In the next decade, AI technology will open an unparalleled opportunity for human progress, but also a chance to fundamentally disrupt the world we live in. AI bots will change the labor/capital paradigm, the structure of labor markets, social organization, and ultimately, the social contract. We may be mistaken, but, in our opinion, due to the dangers inherent in this new technology (Hypothesis No. 1), we must protect human labor and our social institutions. Regarding Hypothesis No. 2, the ethical contempt of the new social contract is still to be defined (Mankiw, Romer, Weil 1990).

Consciousness and creative thinking have always been the domain of man, not machines. Historically, civilizations developed because of how man used the new tools and technologies he created. The advances in communication, transportation, medicine, and material science had the same modus operandi - we had the ultimate "kill 
switch" if the technology went awry. AI is different because, at its core, it has both autonomy and independence from humans. AI will learn, re-program itself, make autonomous decisions, and finally, it will surpass human intelligence many times over, very rapidly, and perhaps before we are even aware of it, especially in those mechanic, standardized, routine productive processes that are commonly found in manufacturing. But what about those more fragmented and focused productive processes, with a kind of tailoring design, which may go as far as reproducing the species? In these cases, the challenges include finding a new ethical code designed for an artificial world with real consequences (Gauthier, D. (1990)).

Over the next 20-30 years, AI will begin to penetrate every aspect of our life in the developed world. Without exaggeration, it will start a new Copernican revolution. Today, we control the technological universe with an on/off switch. In the future universe of AI, we will place technology in the center, to compete with us in the game to control the "kill switch" - and AI may be more audacious because it lacks intuition to anticipate the effect of its actions. But that is the justification for setting a framework equivalent to the laws we humans all must respect. So, Artificial Intelligence should have its own codes of actions, leaving the decisions of last resort to human programming, all properly done within a digital institutional setting.

There are generally three possible futures scenarios we may expect for AI:

First - omnipotent AI, 1000 or 10,000 times more intelligent than we are today, which will make humans obsolete, irrelevant, confused, and vulnerable to alienation.

Second - we will be able to manage AI, and it will enable humans to deal with climate change, pandemics, and diseases, find unlimited sources of energy, explore distant planets, and manage quantum mechanics. We will never give up the on/off switch.

Third - AI will privatize power, divide humanity into classes of winners and losers, and masters of AI with unchallenged control over people who will never be able to cross that barrier. It will establish a permanent elitism of those who merged their brains with $\mathrm{AI}$ and the permanent enslavement of purely biological man. Discussion of all the above scenarios is beyond the scope of this paper. We do not share the doomsday predictions about AI.

\section{Dealing with protection against $\mathrm{Al}$}

Globalization contributed to a decline in growth in developed countries, manufacturing shifted to low-cost countries, and the loss of the technological monopoly, which is quite understandable in terms of Schumpeterian creative destruction. However, the new post-globalization AI economy offers no solution to labor market disequilibria. Following COVID-19, we do not yet have hard data, only preliminary predictions based on available trends. The consulting firm Accenture claims that within the next 
ten years, TVCs (temps, vendors, and contract workers) and bots will dominate production in the 2000 largest companies in the world. There will be no full-time employees outside of the c-suite. If these predictions are to materialize, future labor in developed countries will have no employer-paid health insurance or job security, and there will be no loyalty to the employer. Thus, they will further decline into the category of a disposable production factor. On the other hand, for highly skilled workers, there will be better workplaces, motivation, and integration into the business goal (Ernst \& Young 2018). This will lead to dual labor markets, with important wage differences among different skills groups, stressing the foundation of the welfare state, the way it was known for most of the $20^{\text {th }}$ century.

Globalization has abrogated the post-WWII social contract. Nation-states and their social policies cannot provide adequate jobs, fund the welfare state to guarantee public health and education, control borders, or defend themselves. AI will inflict the final challenge to the Western world's stability unless policymakers, business leaders, governments, and international organizations take decisive action. The relationships between states, corporations, and citizens are at stake if AI replaces qualified labor and is allowed, as some predict, to gain autonomy from the control of state institutions. States have already weakened their influence, and the new AI oligarchy will compete for the dominant position in social organizations. AI will decisively influence the creation of a new state for AI matters.

\section{Conclusions}

1. AI needs to be efficiently controlled for economic and political reasons. Today, the rise of populism, anti-immigration parties, and illiberal democracies represents enough proof that the fabric of the Western social contract cannot cope with the consequences of the weakening of the nation-states and the profit-driven multinationals. Today, multinationals are stronger than states; they make autonomous decisions to export capital, pay taxes or not, employ machines instead of people, change ownership, pay bonuses to its CEOs, take responsibility for employees or not, and decide to pollute the environment or not. AI will empower multinationals' influence and their market power even further.

2. The developers of general AI should be required to develop a "guardian of AI principles", whose sole focus is to preserve human values and life. The guardian AI principles should be programmed by humans inspired by intransient values based on philosophy, ethics, and even spirituality.

3. The most reasonable form of management and control of AI would be to adopt a global convention on AI uses. We think that we should consider signing international conventions, similar to those that were developed to stop the proliferation of nuclear weapons. The potential to harm humans is roughly at a comparable level. 
4. Treat people as an "endangered species" and preserve certain functions and jobs as an inalienable human monopoly and irreplaceable human right. We must restate the Common Declaration of Human Rights in the $21^{\text {st }}$ century.

5. As a crucial element of the global convention referenced in (3) above, a proper regulatory framework is required to install irrevocable "killer switches" on any AI device.

6. Educate the youth, government policymakers, and business managers about the ethical aspects of enabling machines to take their jobs and make decisions that may harm people.

7. Given that productivity growth in the period 2006-2015 was at its lowest post-war level, contrary to the expectation of having higher productivity due to automation already in place, the perception that automation is a threat hanging over the job market like the sword of Damocles is not supported by productivity data. High resource mobility seems to be a more relevant constraint in getting the expected productivity increase thanks to AI.

8. It seems that the real threat from AI will arise from the fact that inward-outward mobility factors will be faster than ever before, and almost beyond the boundaries of what may be considered acceptable both ethically and legally. So, it will be necessary to enact new codes designed for the AI action mode, which will update current laws.

9. AI will decisively influence the creation of a new state for AI matters, different from what we have always known.

\section{References}

Acemoglu, D., Autor, D., Dorn, D., Hanson, G., Price, B. (2014), Import competition and the great U.S. employment sag of the 2000s, "NBER Working Paper 20395", National Bureau of Economic Research, Cambridge, https://doi.org/10.3386/w20395

Annoni, A., Benczur, P., Bertoldi, P., Delipetrev, B., De Prato, G., Feijoo, C., Fernandez Macias, E., Gomez Gutierrez, E., Iglesias Portela, M., Junklewitz, H., Lopez Cobo, M., Martens B., Figueiredo do Nascimento, S., Nativi, S., Polvora, A., Sanchez Martin, J.I., Tolan, S., Tuomi, I., Vesnic Alujevic, L. (2018), Artificial Intelligence: A European Perspective, Publications Office of the European Union, Luxembourg, http://doi.org/10.2760/936974

Breton, T.R. (2013), Were Mankiw, Romer, and Weil Right? A Reconciliation of the Micro and Macro Effects of Schooling on Income, "Macroeconomic Dynamics", 17 (5), pp. 1023-1054, https://doi.org/10.1017/S1365100511000824

Bureau of Labor Statistics, Geneva, 2016.

Caliendo, L., Dvorkin, M., Parro, F. (2015), The impact of trade on labour market dynamics, "NBER Working Paper 21149”, National Bureau of Economic Research, Cambridge, https://doi.org/10.3386/w21149 
Cardarelli, R., Lysinyan, L. (2015), US Total Factor Productivity Decline: Evidence from the U.S. States, "IMF Working Paper", 15/116, https://doi.org/10.5089/9781513520 834.001

Census Bureau, Business Dynamics Statistics, 2014.

Dorn, D., Hanson, G. (2013), The China syndrome: Local labor market effects of import competition in the United States, "NBER Working Paper 18054", National Bureau of Economic Research, Cambridge, https://doi.org/10.3386/w18054

Dorn, D., Hanson, G. (2016), The China shock: Learning from labor market adjustment to large changes in trade, "NBER Working Paper 21906", National Bureau of Economic Research, Cambridge, https://doi.org/10.3386/w21906

Eager, J., Whittle, M., Smit, J., Cacciaguerra, G., Lale-Demoz, E. (2020), Opportunities of Artificial Intelligence, European Parliament, Policy Department for Economic, Scientific and Quality of Life Policies, Bruxelles 2020. https://www.europarl.euro pa.eu/RegData/etudes/STUD/2020/652713/IPOL_STU(2020)652713_EN.pdf (accessed: 9.07.2021).

Elsby, M., Hobijn, B., Sahin, S. (2013), The Decline of the U.S. Labor Share, Brookings Papers on Economic Activity, Brookings Institution Press, Washington, https://doi .org/10.1353/eca.2013.0016

Ernst \& Young (2018), Artificial Intelligence in Europe. Outlook for 2019 and beyond. How 277 benefit the most from AI, Microsoft Western Europe.

Gauthier, D. (1988), Hobbes's Social Contract, Noûs 22, Wiley, https://doi.org/10.2307 $/ 2215553$

Gauthier, D. (1990), Moral Dealing: Contract, Ethics, and Reason, Cornell University Press, Ithaka, https://doi.org/10.7591/9781501745799

International Labor 2014, Report prepared for the G20 Labor and Employment Ministerial Meeting Melbourne, Australia, 10-11 September 2014 and OECD 2015 Report.

Lawrence, R.Z. (2015a), Recent Declines in Labor's Share in US Income: A Preliminary Neoclassical Account, "NBER Working Paper 21296”, National Bureau of Economic Research, Cambridge, https://doi.org/10.3386/w21296

Lawrence, R.Z. (2015b), Explaining recent declines in labour's share in US income, https://voxeu.org/article/explaining-recent-declines-labour-s-share-us-income (accessed: 20.11.2019).

Mankiw, G., Romer, D., Weil, D. (1990), A contribution to the empirics of economic growth, "NBER Working Paper 3541", National Bureau of Economic Research, Cambridge, https://doi.org/10.3386/w3541

Mankiw, G., Romer, D., Weil, D. (1992), A contribution to the empirics of economic growth, "Quarterly Journal of Economics", 107 (2), pp. 407-437, https://doi.org/10 $.2307 / 2118477$

McKinsey \& Company (2018), Digitization, AI, and the future of work: Imperatives for Europe, European Union summit.

Merling, L. (2016), The looming Threat of automation: The data show a different story, Center for Economic and Policy Research, Washington, http://www.cepr.net (accessed: 17.11.2019).

OECD (2018), Sovereign borrowing outlook for OECD countries, Paris.

OECD (2019), SME and entrepreneurship outlook, Paris. 
Rousseau, J.J. (1987), The Basic Political Writings, trans. D.A. Cress, Hackett Publishing Company, Indianapolis, 1987.

Solow, R. (1956), A contribution to the theory of economic growth, "Quarterly Journal of Economics”, 70 (1), pp. 65-94, https://doi.org/10.2307/1884513

Stolper, W.F., Samuelson, P.A. (1941), Protection and real wages, “The Review of Economic Studies. Oxford Journals”, 9 (1), pp. 58-73, https://doi.org/10.2307/2967638

Swan, T. (1956), Economic growth and capital accumulation, "Economic Record", 32 (2), pp. 334-361, https://doi.org/10.1111/j.1475-4932.1956.tb00434.x

World Economic Forum, Davos, (2017), https://www.weforum.org/agenda/archive/ar tificial-intelligence-and-robotics/ (accessed: 17.11.2019).

\section{Sztuczna inteligencja w kontekście globalnej mobilności zasobów. Co z tego wynika?}

Sztuczna inteligencja musi być kontrolowana w bardziej skuteczny sposób. Dziś stoimy w obliczu wzrostu populizmu, postaw antyimigracyjnych i rozwoju nieliberalnych demokracji. Dowodzi to tego, że zachodnie umowy społeczne nie jest już w stanie poradzić sobie z konsekwencjami słabości państwa narodowego i rosnącej roli potężnych międzynarodowych korporacji nastawionych na zysk. Te ostatnie są silniejsze od państwa narodowego, podejmują autonomiczne decyzje o alokacji czynników produkcji na arenie światowej, zatrudniają maszyny zamiast ludzi, biorą odpowiedzialność za pracowników lub nie, decydują o zanieczyszczeniu środowiska toksycznymi odpadami czy nie. Al daje międzynarodowym korporacjom jeszcze więcej mocy.

Słowa kluczowe: sztuczna inteligencja, globalizacja, zatrudnienie

\begin{tabular}{|l|l|}
\hline C. C) by the author, licensee Łódź University - tódź University Press, \\
tódź, Poland. This article is an open access article distributed under \\
the terms and conditions of the Creative Commons Attribution \\
license CC-BY-NC-ND 4.0 \\
(https://creativecommons.org/licenses/by-nc-nd/4.0/) \\
\cline { 2 - 2 } \\
Received: 2020-02-21; verified: 2020-12-04. Accepted: 2021-05-27
\end{tabular}

